\title{
In vitro antagonism of Trichoderma asperellum against Colletotrichum gloeosporioides, Curvularia lunata, and Fusarium oxysporum \\ Antagonismo in vitro de Trichoderma asperellum contra Colletotrichum gloeosporioides, Curvularia lunata, y Fusarium oxysporum
}

\author{
Johana Ramírez-Olier $^{1 a}$, Juan Trujillo-Salazar ${ }^{1 b}$, Víctor Osorio-Echeverri ${ }^{2}$, Margarita Jaramillo-Ciro ${ }^{1 c}$, \\ Liliana Botero-Botero ${ }^{1 \mathrm{~d}}$ \\ ${ }^{1}$ Grupo de Investigaciones en Biodiversidad, Biotecnología y Bioingeniería (Grinbio), Facultad de Ingenierías, \\ Universidad de Medellín, Colombia. Email: ${ }^{a}$ jpramirez@udem.edu.com, \\ b juantrujillos@live.com, ${ }^{\mathrm{c}}$ mmjaramillo@udem.com, ${ }^{\mathrm{d}}$ lbotero@udem.edu.co \\ ${ }^{2}$ Biociencias, Colegio Mayor de Antioquia, Colombia. Email: victor.osorio@colmayor.edu.co
}

Received: 31 August 2018. Accepted: 11 January 2019. Final version: 28 February 2019.

\begin{abstract}
The objective of this study was to evaluate the antagonistic effects of two native isolates of Trichoderma asperellum (GRB-HA1 and GRB-HA2) against the phytopathogenic fungi Colletotrichum gloeosporioides, Curvularia lunata, and Fusarium oxysporum, with the aim of developing biological control agents to replace the use of chemical fungicides. An antagonism assay was performed under in vitro conditions using the dual culture method, and the percentage inhibition of radial growth (PIRG) and the degree of mycoparasitism (grade 0-4) were evaluated after 10 days of culture. Results show that both isolates resulted in 100\% PIRG and grade 4 mycoparasitism in dual cultures against Colletotrichum gloeosporioides and Curvularia lunata although GRB-HA1 led to 70\% PIRG and grade 3 mycoparasitism and GRB-HA2 led to $84 \%$ PIRG and grade four mycoparasitism against $F$. oxysporum. Thus, these native $T$. asperellum isolates show potential for the biological control of diseases caused by phytophathogenic fungi.
\end{abstract}

Keywords: antagonistic fungi; biological control; biopesticides.

\section{Resumen}

El objetivo de este estudio fue evaluar los efectos antagónicos de dos aislados nativos de Trichoderma asperellum (GRB-HA1 y GRB-HA2) contra los hongos fitopatógenos Colletotrichum gloeosporioides, Curvularia lunata y Fusarium oxysporum, para desarrollar agentes de control biológico para sustituir el uso de fungicidas químicos. Se determinó el antagonismo en condiciones in vitro utilizando el método de cultivo dual, y se evaluaron el porcentaje de inhibición del crecimiento radial (PIRG) y el grado de micoparasitismo (grado 0-4). Se encontró que ambos aislamientos resultaron en $100 \%$ PIRG y micoparasitismo de grado 4 en cultivos duales contra Colletotrichum gloeosporioides y Curvularia lunata, aunque GRB-HA1 condujo a $70 \%$ de PIRG y grado 3 , y GRB-HA2 condujo a $84 \%$ de PIRG y grado 4 de micoparasitismo contra $F$. oxysporum. Por tanto, estos aislamientos nativos de $T$. asperellum muestran potencial para el control biológico de enfermedades causadas por hongos fitofatogénicos

ISSN Printed: 1657 - 4583, ISSN Online: 2145 - 8456, CC BY-ND 4.0@)

How to cite: J. Ramírez-Olier, J. Trujillo-Salazar, V. Osorio-Echeverri, M. Jaramillo-Ciro, L. Botero Botero, "In vitro antagonism of Trichoderma asperellum against Colletotrichum gloeosporioides, Curvularia lunata, and Fusarium oxysporum," Rev. UIS Ing., vol. 18, no. 2, pp. 159-166, 2019. doi: 10.18273/revuin.v18n2-2019015 
Palabras clave: biopesticidas; control biológico; hongo antagonista.

\section{Introduction}

Phytopathogenic fungi affect the production of a wide variety of vegetables, cereals and fruits through their effects on both pre- and post-harvest crops [1]. Furthermore, they do not only reduce agricultural production in developing countries like Colombia, where it can result in losses of $5 \%-25 \%$, but also reduce it in developed countries like the United States of America, where losses of 5\%-10\% can occur [2].

Fusarium oxysporum is considered an important phytopathogenic fungus that affects more than 100 plant species, including a wide variety of crops such as banana (Musa spp.) and corn (Zea mays) [3], [4], [5].

In addition, the fungus Colletotrichum gloeosporioides causes anthracnosis in fruits such as avocado (Persea americana), tomato (Solanum lycopersicum) and papaya (Carica papaya) [6], [7] and Curvularia lunata causes foliar spots in several important tropical food crops, including corn and rice (Oryza sativa) [8], [9], [10].

Traditionally, these fungal agricultural diseases have been controlled and prevented using highly toxic synthetic, non-biodegradable pesticides derived from tin and mercury, which have negative environmental and human health impacts [11], [12], [13]. However, there has recently been an increased interest in the use of soil conditioning products to control plant fungal diseases, including antagonistic fungi from the genus Trichoderma.

These fungi naturally occur in soils that favor the development of plants and are capable of inhibiting the growth of other fungi, making them an excellent alternative to chemical products for decreasing the impacts of phytopathogenic fungi [14], [15], [16].

Many studies have shown that fungi in the genus Trichoderma have the potential for controlling $C$. Gloeosporioides, C. Lunata and F. Oxysporum. However, there is still a large amount of uncertainty around their effectiveness, with levels of control ranging from $50 \%$ to $85 \%$ [17], [18], largely depending on the characteristics of the microorganisms and the place from which they were isolated [19], [20], [21]. Therefore, the aim of this study was to evaluate the antagonist activity of two new isolates of Trichoderma asperellum as a strategy for controlling the phytopathogenic fungi $C$. Gloeosporioides, C. Lunata, and F. Oxysporum.

\section{Materials and methods}

\subsection{Microorganisms}

Two antagonist fungi (GRB-HA1 and GRB-HA2) were isolated from colonies of leaf-cutting ants (Atta cephalotes) between March and April 2015. It was found that these fungi negatively affected the growth of the symbiont fungus Leucoagaricus gongylophorus under laboratory conditions during experiments conducted by the Biodiversity, Biotechnology and Bioengineering Research Group (GRINBIO, in Spanish) at the Universidad de Medellin (Medellin, Colombia). Moreover, a commercial antagonistic strain of Trichoderma harzianum (trbio) was donated by Biotropical S.A.S (Antioquia-Colombia) to use as a positive control. The phytopathogenic fungi $C$. Gloeosporioides, C. Lunata, and F. Oxysporum were donated by Safer S.A.S. (Antioquia-Colombia). All the fungi (antagonistic and phytopathogenic) were maintained in the laboratory at the Universidad de Medellin under dark conditions at $25^{\circ} \mathrm{C} \pm 2{ }^{\circ} \mathrm{C}$ in potato dextrose agar (PDA) [22].

\subsection{Characterization and molecular identification}

The identities of the isolates GRB-HA1 and GRB-HA2 were confirmed by DNA sequencing and sequence analysis. DNA was extracted from each isolate using Norgen's Plant/Fungi DNA Isolation Kit according to the manufacturer's instructions (Cat. 26200), and the DNA concentration was estimated by measuring the absorbance at $260 \mathrm{~nm}$ (Nanodrop). Polymerase chain reaction (PCR) amplification of the internal transcribed spacer (ITS) was then performed using the primers ITS1 (5' TCCGTAGGTGAACCTGCGG 3') and ITS4 (5' TCCTCCGCTTATTGATATGC 3') for both isolates, although amplification of the beta-tubulin gene was performed using the primers ASP_Bt2a (5' GGTAACCAAATCGGTGCTGCTTTC 3') and ASP Bt2b (5' ACCCTCAGTGTAGTGACCCTTGGC $3^{\prime}$ ) for the GRB-HA1 isolate. Sequencing was performed using the Sanger/capillary method for both strands, and the obtained sequences were debugged and assembled using the programs Cap3 and ebiox version 1.5.1. The sequences were then compared to ITS sequences from the GenBank database using BLAST (http://www.ncbi.nlm.nih.gov/). A phylogenetic analysis was conducted using the package MEGA version 6.0, and the neighbor-joining and maximum-likelihood methods were used to construct phylogenetic trees with 1,000 bootstrap replicates. 


\subsection{Antagonism assay}

The antagonism assay was performed on PDA in Petri dishes using the dual culture method proposed by [22]. Mycelial plugs (5 $\mathrm{mm}$ diameter) were obtained from cultures of the fungal antagonists (GRB-HA1, GRBHA2, and trbio) and pathogens (C. Gloeosporioide, $C$. Lunata, and $F$. Oxysporum) after 5 days of incubation at $25^{\circ} \mathrm{C} \pm 2{ }^{\circ} \mathrm{C}$ under dark conditions, and pairs of antagonists and pathogens were placed $6 \mathrm{~cm}$ apart on the same Petri dish (Figure 1). The radial growth (RG) of the fungi was then measured using a vernier caliper after 10 days of incubation at $25^{\circ} \mathrm{C} \pm 2{ }^{\circ} \mathrm{C}$ under dark conditions. Dual confrontation tests were performed for each antagonistic fungus (the native isolates GRB-HA1 and GRB-HA2 and the commercial isolate trbio) with each pathogenic fungus ( $C$. Gloeosporioides, $C$ lunata, and $F$. Oxysporum). PDA medium inoculated only with the test pathogens served as controls to determine the capacity of growth of the pathogenic fungi. Thus, there were 12 treatments in total, each of which was performed in triplicate.

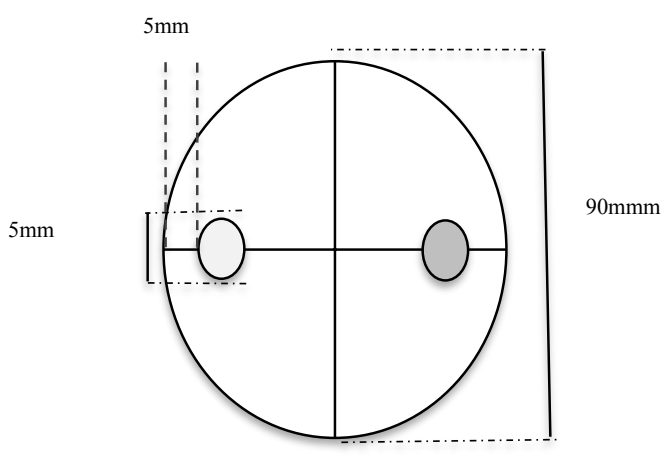

Figure 1. Scheme of the process of dual confrontation of pathogenic and antagonistic fungi in Petri dishes.

The percentage inhibition of radial growth (PIRG) was calculated after 12 days of culture using Ecuation (1):

$$
\operatorname{PIRG}(\%)=\mathrm{KR}-\mathrm{R} 1 / \mathrm{KR} * 100
$$

Where KR represents the distance (in $\mathrm{mm}$ ) from the point of inoculation to the colony margin on dishes that were inoculated only with the test pathogens (i.e., the controls), and R1 represents the distance of fungal growth from the point of inoculation to the colony margin on the treated dishes in the direction of the antagonist [23]. PIRG was categorized from 0 to 4 using a growth inhibition category (GIC) scale, where $0=$ no growth inhibition, $1=1 \%-25 \%$ growth inhibition, $2=26 \%-50 \%$ growth inhibition, $3=51 \%-75 \%$ growth inhibition and 4 $=76 \%-100 \%$ growth inhibition (table 1 ).
Table 1. Scale used to evaluate the antagonist ability of the fungi under in vitro conditions.

\begin{tabular}{|c|c|}
\hline Grade & Antagonist capability \\
\hline 0 & $\begin{array}{l}\text { No invasion of the colony by pathogenic } \\
\text { fungi. }\end{array}$ \\
\hline 1 & $\begin{array}{l}\text { Invasion of } 1 / 4 \text { of the surface of the colony } \\
\text { by pathogenic fungi. }\end{array}$ \\
\hline 2 & $\begin{array}{l}\text { Invasion of } 1 / 2 \text { of the surface of the colony } \\
\text { by pathogenic fungi. }\end{array}$ \\
\hline 3 & $\begin{array}{l}\text { Total invasion of the surface of the colony } \\
\text { by pathogenic fungi. }\end{array}$ \\
\hline 4 & $\begin{array}{c}\text { Total invasion of the surface of the colony } \\
\text { by pathogenic fungi with associated } \\
\text { sporulation. }\end{array}$ \\
\hline
\end{tabular}

The results were analyzed by variance analysis with the statgraphics Centurion 2015 software, and significant differences were estimated using the least significant difference (LSD) test. For all analyses, $\mathrm{p}<0.05$ was considered significant.

\section{Results and discussion}

\subsection{Characterization and molecular identification of GRB-HA1 and GRB-HA2}

The GRB-HA1 isolate was grouped with the species $T$. Asperellum with $90 \%$ bootstrap support, and there was a distance of only 0.006 between their sequences in the distance matrix (figure 2). . Similarly, the GRB-HA2 isolate was grouped with T. Asperellum with 94\% bootstrap support, and there was a distance of 0.002 between their sequences (figura3) (table2).

\subsection{Antagonistic analysis}

It was found that both strains of $T$. Asperellum (GRBHA1 and GRB-HA2) had a higher antagonistic capacity than the commercial strain of T. Harzianum (trbio).

There was no significant difference between the activities of GRB-HA1 and GRB-HA2 in dual cultures with C. Gloeosporioides and C. Lunata (PIRG $=100 \% \pm 0 \%$ ), but both had higher PIRG values than the commercial strain trbio (PIRG $=49 \% \pm 7 \%$ for C. Gloeosporoides and $53 \%$ $\pm 6 \%$ for $C$. Lunata) (figure 4). Furthermore, both GRBHA1 and GRB-HA2 exhibited a higher degree of mycoparasitism of $C$. Gloeosporioides and $C$. Lunata (grade 4) than the commercial trbio isolate (grade 3) (table 2). 


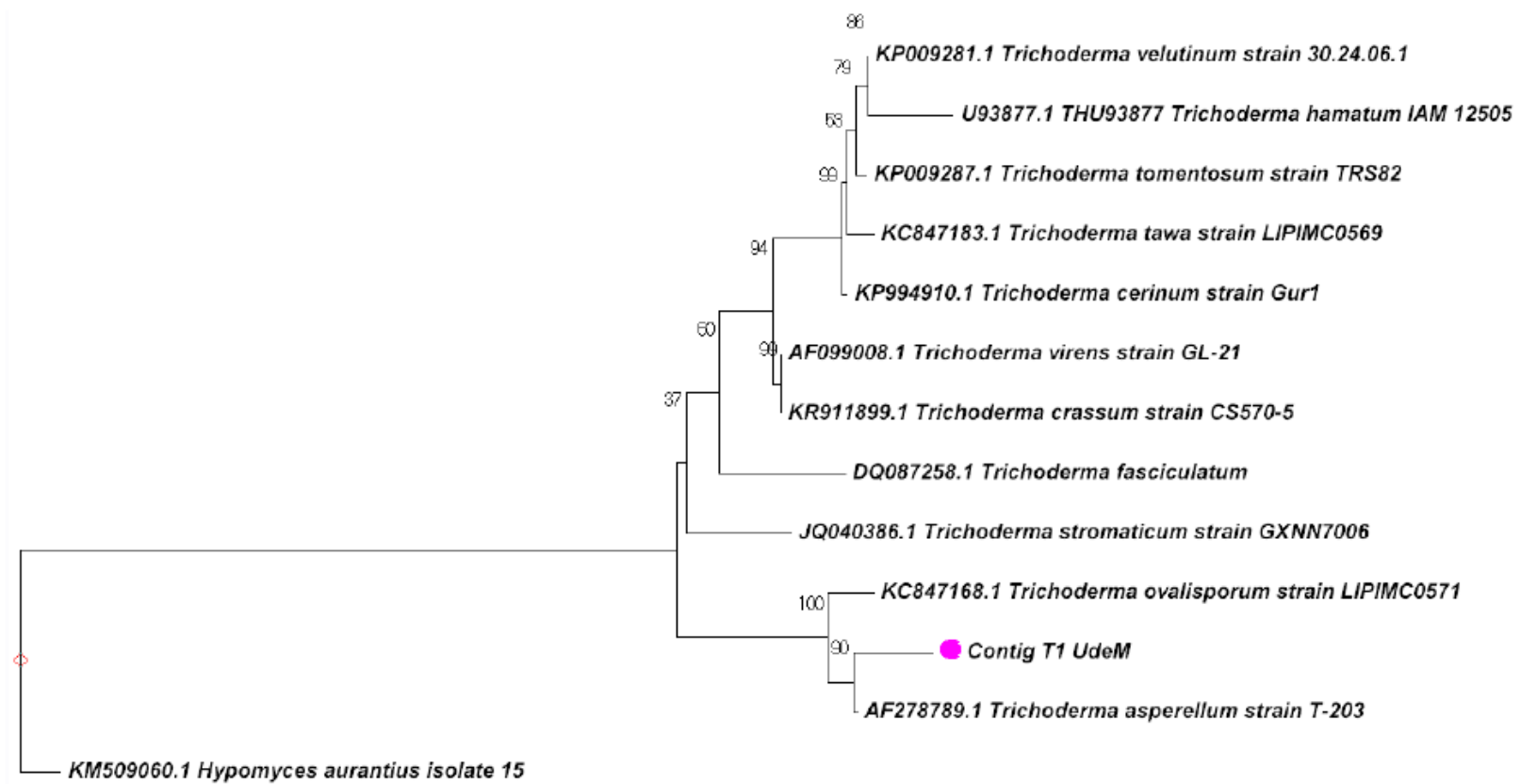

Figure 2. Phylogenetic analysis of the internal transcribed spacer (ITS) region, showing the position of GRB-H1 (Conting T1 udem) in the genus Trichoderma. The evolutionary history was inferred using neighborjoining and a distance matrix.

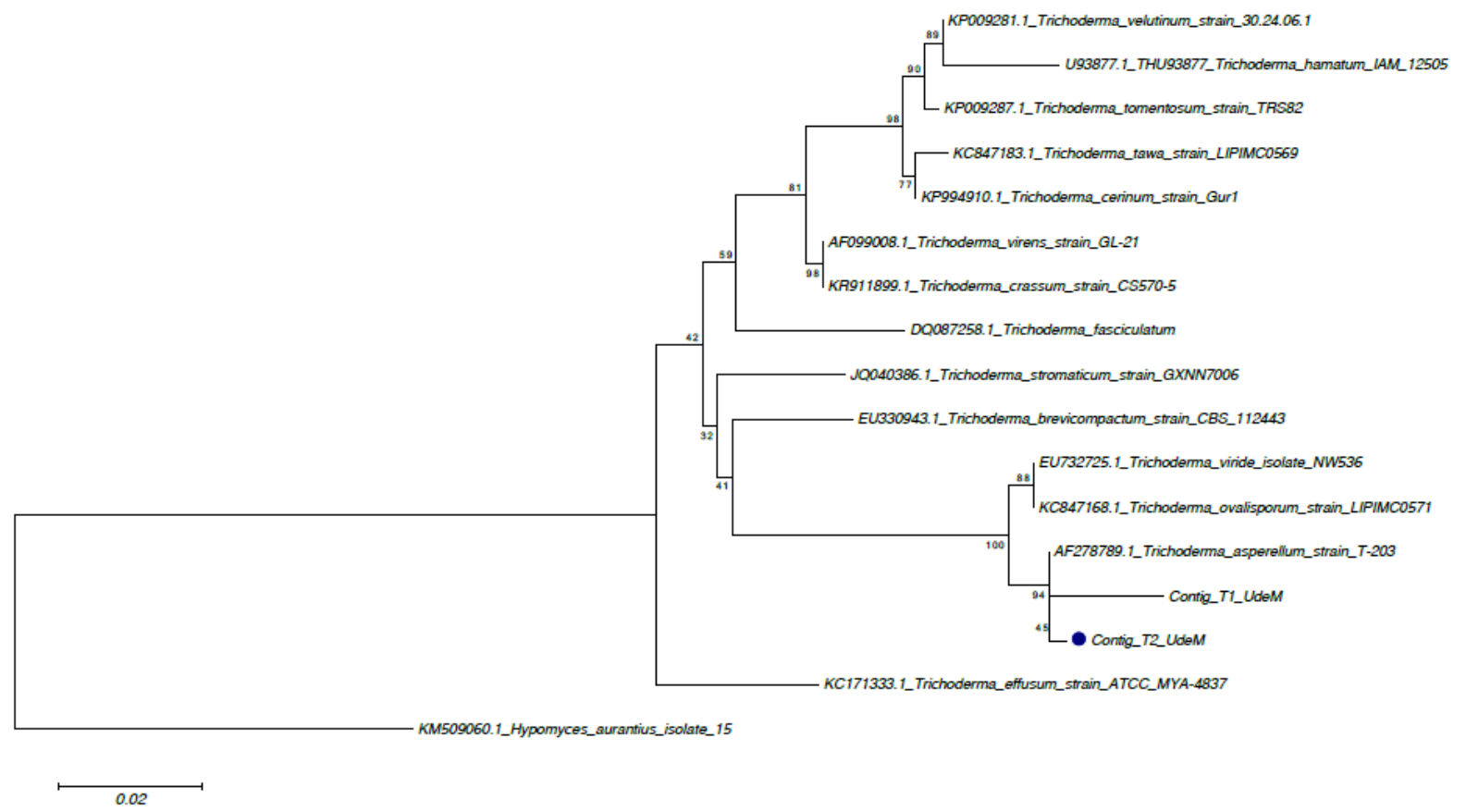

Figure 3. Comparative phylogenetic analysis of the internal transcribed spacer (ITS) region, showing the position of GRB-H1 (Conting_T1_udem) y GRB-H2 (Conting_T2_udem) into the genus Trichoderma. The evolutionary history was inferred using neighbor-joining and a distance matrix. 
Table 2. Characterization and molecular identification of antagonistic isolates of T. Asperellum GRB-HA1 and GRB-

HA2.

\begin{tabular}{|c|c|c|c|c|}
\hline Sample & Best hit & E-value & Query cover & $\begin{array}{c}\text { Percent } \\
\text { identity }\end{array}$ \\
\hline GRB-HA1 & $\begin{array}{c}\text { Trichoderma asperellum strain TA4 18S } \\
\text { ribosomal RNA gene, partial sequence; } \\
\text { internal transcribed spacer 1, 5.8S } \\
\text { ribosomal RNA gene and internal } \\
\text { transcribed spacer 2, complete sequence; } \\
28 \text { S ribosomal RNA gene, partial } \\
\text { sequence }\end{array}$ & 0 & $100 \%$ & $98 \%$ \\
\hline GRB-HA2 & $\begin{array}{c}\text { Trichoderma asperellum strain ZWPBG7 } \\
\text { 18S ribosomal RNA gene, partial } \\
\text { sequence; internal transcribed spacer 1, } \\
\text { 5.8S ribosomal RNA gene and internal } \\
\text { transcribed spacer 2, complete sequence; } \\
\text { and 28S ribosomal RNA gene, partial } \\
\text { sequence }\end{array}$ & 0 & $100 \%$ & $99 \%$ \\
\hline
\end{tabular}

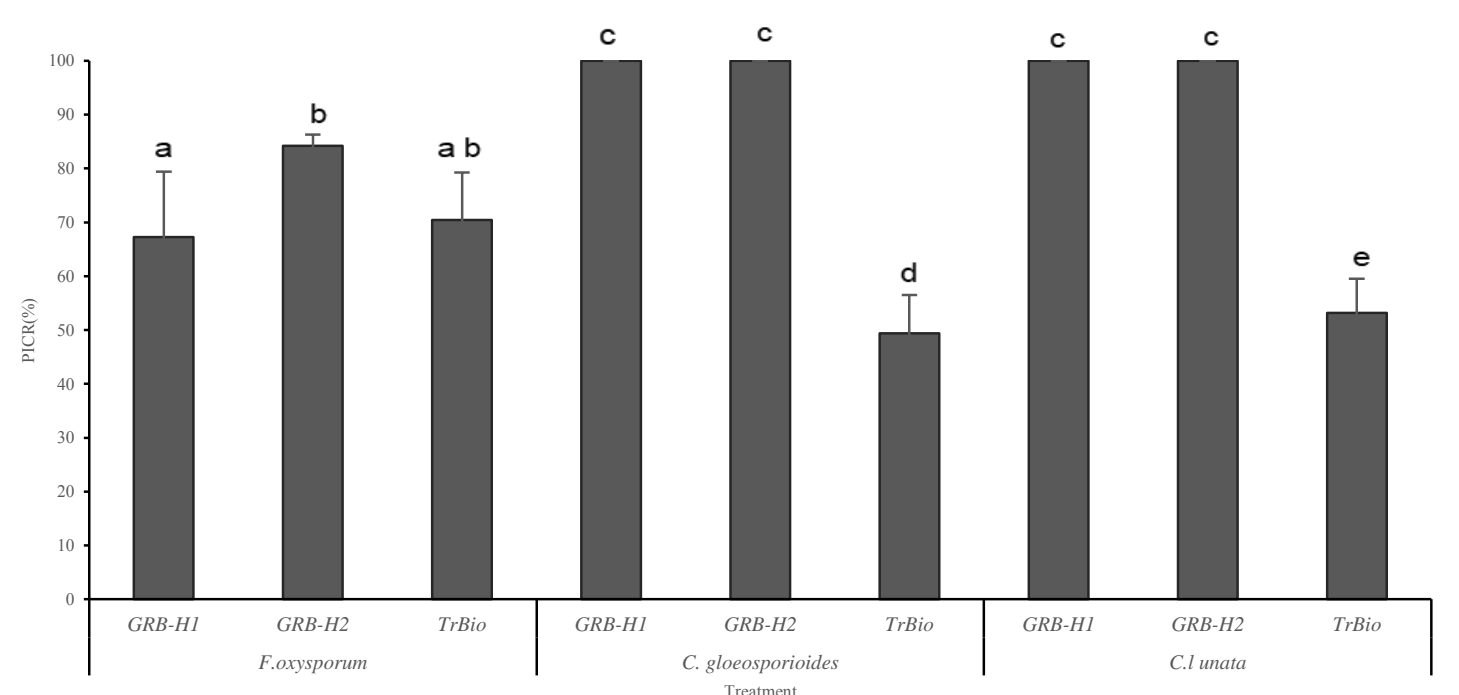

Figure 4. Percentage inhibition of radial growth (PIRG) in dual cultures of Trichoderma isolates (GRB-HA1, GRBHA2, and trbio) against the phytopathogenic fungi Colletotrichum gloeosporioides, Curvularia lunata, and Fusarium oxysporum. The bars indicate the standard errors. Bars with different letters within a treatment were significantly different [least significant difference (LSD) test, $\mathrm{p}<0.05$ ].

[17] previously obtained lower antagonism values of $61 \%-65 \%$ PIRG and mycoparasitism grade 4 against $C$. Gloeosporioides and argued that this showed that the microorganism they tested had potential for controlling this phytopathogenic fungus. Furthermore, several studies have recently evaluated the antagonistic power of Trichoderma spp. Against $C$. Lunata, with [10] achieving 55\% PIRG with T. Aureoviride. This is similar to the value found in the present study with the commercial trbio isolate but below the values obtained with the native isolates GRB-HA1 and GRB-HA2. Thus, both native isolates of T. Asperellum (GRB-HA1 and GRB-HA2) show great promise for controlling $C$. Gloeosporioides and $C$. Lunata. However, these findings will need to be corroborated under field conditions. 
In contrast with these findings, there was no significant difference in the control capability of trbio and the GRBHA1 and GRB-HA2 isolates against $F$. Oxysporum (figure 4). The highest PIRG against $F$. Oxysporum was obtained using GRB-HA2 $(84 \% \pm 2 \%)$, followed by the commercial trbio isolate $(70 \% \pm 9 \%)$, and finally GRBHA1 $(67 \% \pm 12 \%)$ : the degree of mycoparasitism was categorized as stage 4 for the GRB-HA2 isolate and stage 3 for the GRB-HA1 and trbio isolates ( table 3). These findings are similar to those obtained by [24], who reported that three $T$. Harzianum isolates ( $\operatorname{Tr} 16$, and Tr08) resulted in $78 \%$ and $68 \%$ radial growth inhibition of F. Solani, respectively.

Table 3. Degree of mycoparasitism in dual cultures of the native Trichoderma asperellum isolates GRB-HA1 and GRB-HA2 and the commercial Trichoderma harzianum isolate trbio against the phytopathogenic fungi Colletotrichum gloeosporioides, Curvularia lunata, and Fusarium oxysporum.

\begin{tabular}{|c|c|}
\hline Antagonism & $\begin{array}{c}\text { Degree of } \\
\text { mycoparasitism }\end{array}$ \\
\hline $\begin{array}{c}\text { GRB-HA1 vs } C . \\
\text { Gloeosporioides }\end{array}$ & 4 \\
\hline $\begin{array}{c}\text { GRB-HA2 vs } \text {. } \\
\text { Gloeosporioides }\end{array}$ & 4 \\
\hline $\begin{array}{c}\text { Trbio vs } \text { C. } \\
\text { Gloeosporioides }\end{array}$ & 3 \\
\hline GRB-HA1 vs C. Lunata & 4 \\
\hline GRB-HA2 vs C. Lunata & 4 \\
\hline Trbio vs C. Lunata & 3 \\
\hline $\begin{array}{c}\text { GRB-HA1 vs } F . \\
\text { Oxysporum }\end{array}$ & 3 \\
\hline GRB-HA2 vs $F$. & 4 \\
\hline Oxysporum & 3 \\
\hline Trbio vs F. Oxysporum & \\
\hline
\end{tabular}

\section{Conclusions}

The antagonist capabilities of the native Trichoderma isolates GRB-HA1 and GRB-HA2 vary depending on the microorganism they are trying to control.

The native Trichoderma isolates GRB-HA1 and GRBHA2 can completely inhibit the growth of Colletotrichum gloeosporioides and Curvularia lunata

The GRB-HA2 isolate is most effective in controlling Colletotrichum gloeosporioides, Curvularia lunata, and F. Oxysporum.

The native Trichoderma isolates GRB-HA1 and GRBHA2 have potential for the biological control of diseases caused by Colletotrichum gloeosporioides, Curvularia lunata, and F. Oxysporum.

\section{Acknowledgements}

We thank the Universidad de Medellín and the Faculty of Health Science of Institución Universitaria Colegio Mayor de Antioquia for its institutional support. We are grateful to the GRINBIO human team for their active participation in the experimental development of the project, as well as to the laboratory center and the Engineering Research Center (in Spanish CEIN) of the Universidad de Medellín for its administrative support. Thanks are also due to the Department of Science, Technology and Innovation in Colombia (in Spanish COLCIENCIAS) for their economic support.

\section{References}

[1] G. Juárez-Becerra, M. Sosa-Morales, A. López-Malo, "Hongos fitopatógenos de alta importancia económica: descripción y métodos de control”, TSIA, vol. 4, no. 2, p.14-23, 2010.

[2] "Deterioro poscosecha de las frutas y Hortalizas frescas por hongos y bacterias," FHIA informa, San Pedro Sula, Cortés, Hond., Dic. 2007 [En línea]. Disponible en: http://www.fhia.org.hn/ dowloads/fhia_ informa/fhiainfdic2007.pdf

[3] J. Gonzáles-Cardenas, J. Maruri-Carcía, A. GonzálesAcosta, "Evaluación de diferentes concentraciones de Trichoderma asperillum contra Fusarium oxysporum agente causal de pudrición de plántulas en papaya (Carica papaya L.) En Tuxpan, Veracruz, México," Rev. UDO Agrícola, vol. 5, pp. 45-47, 2005.

[4] C. Suárez, R. Fernández, N. Valero, R. Gámez, A. Páez, "Antagonismo in vitro de Trichoderma harzianum Rifai sobre Fusarium solani (Mart.) Sacc., asociado a la marchitex en maracuyá", Rev. Colombiana de Biotecnología, vol. 10, no. 2, pp. 35-43, 2008. doi: 10.15446/rev.colomb.biote

[5] W, Flores-Bazauri, J. Chico-Ruíz, L. Cerna-Rebaza, "Actividad antagónica in vitro de Clonostachys rosea sobre Fusarium axysporum, Alternaria solani y Botrytis cinerea", Rev. REBIOL, vol. 35, no. 1, pp. 34-42, 2015.

[6] E. S. R., J. M. G., and N. M., "La Infección de Colletotrichum gloeosporioides (Penz.) Penz. y Sacc. en Aguacatero (Persea americana Mill.): Aspectos Bioquímicos y Genéticos," Rev. Mex. Fitopatol., vol. 27, no. 1, pp. 53-63, 2009. 
[7] L. Machado, S. Matsumoto, G. Cuzzuol, L. Oliveira, "Influence of laboratory cultivation on species of Rhodophyta physiological evaluations and antifungal activity against phytopathogens", Rev. Cienc. Agron., vol. 45 , no. 1, pp. 52-61, 2014.

[8] F. Varón, G. Sarria, Enfermedades del maíz y su manejo. Palmira: ICA Fenalce, 2007.

[9] D. Sardinha, D. Silva et al., "Fungos e nematóides fitopatogênicos associados ao cultivo de flores tropicais em São Luís - MA", Summa Phytopathologica, vol. 38, no. 2, pp. 159-162, 2012. doi: 10.1590/S010054052012000200010 .

[10] R. Sneha, K. Satya-Prasad, "Antagonistic activity of Trichoderma aureoviride against Fusarium solani and Curvularia clavata," Journ. Of Intern. Acad. Res. For Multidisciplinary, vol. 2, no. 10, pp. 422-427, 2014.

[11] G. C. Papavizas, "Trichoderma and Gliocladium: Biology, Ecology, and Potential for Biocontrol," Аппи. Rev. Phytopathol., vol. 23, no. 1, pp. 23-54, 1985.

[12] M. H. Badii, J.L. Abreu, "Control biológico una forma sustentable de control de plagas", Daena, vol 1, pp. 82-90, 2006.

[13] M. Verma, S. K. Brar, R. D. Tyagi, R. Y. Surampalli, and J. R. Valéro, "Antagonistic fungi, Trichoderma spp.: Panoply of biological control," Biochem. Eng. J., vol. 37, no. 1, pp. 1-20, 2007.

[14] G. E. Harman, "Overview of Mechanisms and Uses of Trichoderma spp.," Phytopathology, vol. 96, no. 2, pp. 190-194, Feb. 2006. doi: 10.1094/PHYTO-96-0190

[15] F. Matarese, S. Sarrocco, S. Gruber, V. SeidlSeiboth, and G. Vannacci, "Biocontrol of Fusarium head blight: interactions between Trichoderma and mycotoxigenic Fusarium," Microbiology, vol. 158, no. 1, pp. $98-106,2012$. doi: $10.1099 / \mathrm{mic} .0 .052639-0$

[16] B. Martínez, Y. Obret, S. Pérez, Y. Reyes, "Antagonismo in vitro de cepas de Trichoderma asperellum frente a Sarocladium oryzae (Sawada) W. Gams \& D. Hawksworth." Rev. Protección Veg., vol.29, no. 2, pp. 106-111, 2014.

[17] V. Gaviria-Hernández, L. F. Patiño-Hoyos, y A. Saldarriaga-Cardona, "Evaluación in vitro de fungicidas comerciales para el control de Colletotrichum spp., en mora de castill," RCTA, vol. 14, no. 1, pp. 67-75, 2013.
[18] M.T. Aktar, K.S. Hossain, M.A. Bashar, "Antagonistic potential of rhizosphere fungi against leaf spot and fruit rot pathogens brinjal," Bangladesh Journ. of Botany, vol. 43, no. 2, pp. 213-217, 2014.

[19] B. K. Mishra, R. K. Mishra, R. C. Mishra, A. K. Tiwari, R. S. Yadav, and A. Dikshit, "Biocontrol efficacy of Trichoderma viride isolates against fungal plant pathogens causing disease in Vigna radiata L," Arch. Appl. Sci. Res., vol. 3, no. 2, pp. 361-369, 2011.

[20] J. A. O., S. A. O., J. O., and J. P. K., “Assessment of trichoderma isolates for virulence efficacy on fusarium oxysporum f. sp. phaseoli," Trop. Subtrop. Agroecosystems, vol. 13, pp. 99-107, 2011.

[21] T. G. Kim and G. R. Knudsen, "Relationship between the biocontrol fungus Trichoderma harzianum and the phytopathogenic fungus Fusarium solani f.sp. pisi," Appl. Soil Ecol., vol. 68, pp. 57-60, 2013.

[22] N. J. Fokkema, "Fungal antagonisms in the phyllosphere," Ann. Appl. Biol., vol. 89, no. 1, pp. 115119. doi: $10.1111 /$ j.1744-7348.1978.tb02582.x

[23] L. Korsten, E. S. De Jager, E. E. De Villiers, "Evaluation of bacterial epiphytes isolated from avocado leaf and fruit surfaces for biocontrol of avocado postharvest diseases," Plant Disease, vol. 79, n. ${ }^{\circ} 11$, pp. 1149-1156, 1995.

[24] S. A. Wani et al., "Incidence of Fusarium wilt of chilli (Capsicum annum L.) in Kashmir valley and its management by Trichoderma spp," MYCOPATH, vol. 12, no. 1, pp. 1-8, 2014. 